\title{
Internet Reviews
}

Code Talk. Access: http://www.codetalk. fed.us/.

The U.S. Department of Housing and Urban Development's Office of Native Ameri-

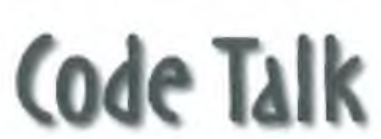
can Programs (ONAP) hosts this federal interagency $\mathrm{Na}-$ tive American Web site, designed to connect Native American communities to relevant information and resources available from government agencies and other federal organizations. The site is clean, well organized, easy to use, and wonderfully devoid of commercial advertising.

Code Talk is an interesting complement to the well-established NativeWeb (www. nativeweb.com), a volunteer-run Web site with a grassroots perspective. While NativeWeb links to many nonprofit, nongovernmental, and even controversial sites, Code Talk points primarily to agency and organizational links proffering the official government line. It even includes a "kid safe" link to agency-sponsored children's pages.

"Key Topic Areas" connects to more than a dozen agencies and related gateways, including Community Development, Health, Housing, Tribal Court Clearinghouse, Bureau of Indian Affairs, Indian Education, Environmental Resources, Urban Indians, and more. "Calendar of Events" notes relevant national conferences, institutes, meetings, and training schedules for a full year. "Resources and Tools" provides yet another arrangement of contacts, with some duplication.

Although the agency links seem to be well maintained, some aspects of this site are seriously neglected. Under "Current Issues," for instance, postings are six months to two years old. Only "Indian News Links," which links directly to tribal newspapers, contains current news. Even the latest posted issue of ONAP's newsletter, Dreamcatcher, is from December 1999. The search engine also does not work, although functionality has been promised "in the near future." The site map is useful, but no substitute for a good search engine.
The strength of Code Talk is its role as a gateway to the federal and state programs and opportunities directly available for Native Americans in the United States. As such, it may be more useful to those working on behalf of Native Americans, or to Native American organizations and individuals, than it would be for researchers, historians, and students.

On the other hand, it contains a wealth of information for anyone researching government programs for Native Americans. In addition, the site includes links to related sites in genealogy, laws and treaties, music, pottery, literature, sports, and more. The collection of $\mathrm{Na}$ tive American news publications alone is worth investigating. For those seeking one place to find federal grants, programs, assistance, publications, and events of interest to Native Americans in the United States, this site could be a real boon.-Barbara Valentine, Linfield College, bvalen@linfield.edu

Invasivespecies.gov. Access: http:// invasivespecies.gov/.

Invasive plant species are spreading at the rate of thousands of acres per day, causing the decline of native species and reducing the potential for survival for many threatened or endangered species. Dangerous invasive animal species, such as the fire ant and the Africanized honeybee, are invading our backyards, driving us - itching and screaming - into the relative safety but boring confinement of our own homes. Recognition of the adverse impact of invasive species has led to the creation of numerous information resources, a significant number of which are now easily accessed via the invasive species site.

In February 1999, President Bill Clinton issued Executive Order 13112, which established the National Invasive Species Council (NISC), whose duties included the "establishment of a coordinated, up-to-date information-sharing system." To meet this mandate, an invasive spe-

Joni R. Roberts is associate university librarian for public services and collection development at Willamette University, e-mail: jroberts@willamette.edu, and Carol A Drost is associate university librarian for technical services at Willamette University, e-mail: cdrost@willamette.edu 


\section{invasivespecies.gov}

cies Web site was developed and is maintained by the National Agricultural Library (NAL) of the U.S. Department of Agriculture. Dozens of partners, most prominently the National Biological Information Infrastructure (NBII), have provided content and links to hundreds of information resources, resulting in a site of extraordinary complexity and depth.

Invasivespecies.gov is a significant information resource, but the dual NAL and NBII navigation tools, which have confusing button topic labels, impair its utility. Although the labels may lead one to think links and/or resources are duplicated by NAl and NBII, such is usually not the case; each agency's buttons provide links to unique resources. Using the browser's "back" button to trudge from NBII sites to the invasivespecies.gov homepage to access NAL links is a tedious exercise indeed.

Despite its inherent navigational difficulties, the invasive species site is a useful resource for researchers, college students, educators, and the general public. An alphabetical list of Web site partners provides links to an extraordinary diversity of sources for comprehensive information on a wide range of invasive species. The adventurous explorer will find sophisticated species search engines and useful, interesting links to systematics collections and natural history museum sites, taxonomic databases, agencies providing invasive species control and eradication information, news alerts, geospatial technologies, metadata, regional information, and much more. The invasive species Web site is a unique resource and is highly recommended.-Susan B. Case, University of Kansas, scase@ku.edu

Internet Sacred Text Archive. Access: http://www.sacred-texts.com/index.htm.

Internet Sacred Text Archive (or SacredTexts) is a nonprofit archive of religious texts privately maintained by J. B. Hare of Santa Cruz, California, and is not affiliated with any religious organization or institution. The main index, which offers "a quiet place in cyberspace devoted to religious tolerance and scholarship," lists three general links: "World Religions," "Traditions," and "Mysteries." "World Religions" contains the primary text(s) from the major traditions. There are also links to secondary sources.
Scholarship in religious studies divides the world's primary religions into three main groups: Western monotheism (Christianity, Islam, and Judaism), religions of South Asia (Hinduism and Buddhism), and the "third stream" of Chinese religion (Confucianism and Taoism, and perhaps Shintoism). Sacred-Texts does the patron a service by including all of these traditions under "World Religions." Since no annotation is provided, some perspective is necessary in navigating the site. "Buddhism" contains links to both Zen and Tibetan Buddhism, but no mention is made of Theraveda Buddhism, the more conservative branch of Buddhism. The only English Bible available under "Christianity" is the 17 th-century King James Version. "Islam" includes the Koran and a link to Sufism (an ascetic and mystical Muslim sect). However, no distinction is made between the two main branches of Islam: Sunni and Shi'ite.

The second link, "Traditions," leads the researcher to "Australian" (Aboriginal texts), "African Religions" (broken down into Bantu, West and South African, and Caribbean), "Egyptian" (including the authoritative translation of The Book of the Dead by Wallis Budge), "Legends and Sagas" (including Arthurian, Celtic, and Icelandic materials), and "Native American" (including Aztec, Cherokee, Hopi, Navajo, and Zuni legends) resources. In cases where no primary texts are available (as in Shamanism or certain African tribal religions), the oral traditions have been retold and transcribed.

The third link, "Mysteries," contains materials also found in the "World Religion" section under the heading "Paganism." Material such as the predictions of Nostradamus and the tales of Atlantis are located here. Curiously, the mystery religions from Greece and the Mediterranean are omitted.

The main page contains a site map, which lists the links alphabetically. Sacred-Texts, while easy to navigate, does not lend itself to browsing. At some point, the Internet searcher is going to need a concordance or a guide to the primary texts. Many of the texts are also available to purchase as PDF files or on CDROM. Sacred-Texts is a valuable resource for what it purports to provide: an archive of primary religious texts.-Wendell Jobnson, Waubonsee Community College,wjobnson@ mail.wcc.cc.il.us 